\title{
Histopathological findings of Fasciola hepatica infection in non-native European hare (Lepus europaeus) in Southern Chile
}

Achados histopatológicos da infecção por Fasciola hepatica em lebre europeia não-nativa (Lepus europaeus) no Sul do Chile

\author{
Pablo Oyarzún-Ruiz ; Cristina Alvelo²; Frank Vera ${ }^{3}$; Manuel Moroni ${ }^{2 *}$ \\ ${ }^{1}$ Programa de Doctorado en Ciencias Veterinarias, Facultad de Ciencias Veterinarias, Universidad de Concepción, Chillán, Chile \\ ${ }^{2}$ Unidad de Anatomía Patológica Veterinaria, Facultad de Ciencias Veterinarias, Universidad Austral de Chile, Valdivia, Chile \\ ${ }^{3}$ Carrera de Medicina Veterinaria, Facultad de Medicina Veterinaria, Universidad San Sebastián, Puerto Montt, Chile
}

Received June 7, 2018

Accepted August 20, 2018

\begin{abstract}
Fasciola hepatica is a parasite introduced in America from Europe, being considered of concern for public health and animal production, especially in countries with endemic areas as occur in Chile. In this country, the research has been focused mainly in domestic ruminants, with native and introduced wildlife being largely ignored. Thus, the aim of this study was to report the infection by Fasciola hepatica in an introduced mammal, the European hare, which is distributed along a vast area of the country. One in 42 hares hunted showed histological lesions compatible with $F$. hepatica, and harbored a parasitic load of 6 liver flukes. This is the first report of this lagomorph acting as host of this helminth in the country and the third in South America. Yet, we found no previous reports regard the pathology of this fluke in the species. Thus, we emphasize the importance of more studies regarding introduced mammals which could be acting as reservoirs for this important fluke.
\end{abstract}

Keywords: Fasciola hepatica, hepatic lesions, Lepus europaeus, reservoirs, Chile.

\begin{abstract}
Resumo
Fasciola hepatica é um parasita de origem europeia introduzido na América, de importância em saúde pública e animais de produção, especialmente em países com áreas endêmicas, como ocorre no Chile. Neste país, a pesquisa foi focada principalmente em ruminantes domésticos, com a fauna nativa e introduzida sendo amplamente ignorada. O objetivo desse trabalho é relatar a infecção por Fasciola hepatica em lebre europeia, espécie distribuída em vasta extensão do país. Uma em 42 lebres caçadas, mostrou lesões histológicas compatíveis com infestação por $F$. hepatica, alojando 6 vermes hepáticos. Este é o primeiro relato deste lagomorfo apresentando este tipo de parasitismo no Chile, o terceiro na América do Sul. No entanto, não encontramos relatos anteriores sobre a patologia deste acaso na espécie. Este relato salienta a importância de mais estudos considerando espécies introduzidas, as quais podem ser reservatórios desse importante parasita.
\end{abstract}

Palavras-chave: Fasciola hepatica, lesōes hepáticas, Lepus europaeus, reservatórios, Chile.

Fasciola hepatica Linnaeus, 1758 (Platyhelminthes: Fasciolidae) is responsible of fascioliasis, an important parasitic disease that causes important economic losses by organ condemnation, decreases in milk and meat production and mortality of livestock, moreover is a public health concern disease. The indirect lifecycle involves lymnaeid snails as intermediate hosts, releasing cercariae which encyst as metacercariae, the infective stage, in vegetation. The latter is ingested by the definitive hosts; e.g. cattle, sheep, camelids, pigs, even humans. The fluke reaches the liver, where

*Corresponding author: Manuel Moroni. Unidad de Anatomía Patológica Veterinaria, Instituto de Patología Animal, Facultad de Ciencias Veterinarias, Universidad Austral de Chile, casilla 567, Valdivia, Chile. e-mail: manuelmoroni@uach.cl it matures and release eggs through bile, being eliminated to the environment through the feces. This fluke was originated in the Eurasian near east region, reaching an almost worldwide distribution, being present in several countries from Africa, Americas, Asia, Europe and Oceania (MAS-COMA et al., 2007, 2009; VALERO et al., 2012). In Chile, domestic mammals and wild mammals such as the European rabbit (Oryctolagus cuniculus), Huemul (Hippocamelus bisulcus) and Southern pudu (Pudu puda) have been reported as F. hepatica hosts (ALCAÍNO et al., 1988; APT et al., 1993; POVILITIS, 1998; ALCAÍNO \& GORMAN, 1999; FUGASSA, 2015). Furthermore, the World Health Organization (WHO) consider Chile as an endemic country for human fascioliasis (WHO, 2018). 
The European hare Lepus europaeus Pallas, 1778 (Mammalia: Lagomorpha) is a non-native mammal introduced from Europe during the XIX century for commercial activities, currently present in some countries of South America, e.g. Argentina, Brazil, Chile and Uruguay. In Chile, the species has a wide distribution with a well stablished population from Copiapó to Magallanes, thus being considered a pest (JAKSIC et al., 2002). Regard local parasitological surveys, there is a unique study attempted by González-Acuña et al. (2005) with no positive results regard the liver fluke.

A total of 42 European hares were hunted between June 2015 and June 2016 in an area of pasture used for grazing livestock in Futrono commune, Los Ríos region, Chile $\left(40^{\circ} 08^{\prime} 00^{\prime \prime} \mathrm{S}\right.$; $\left.72^{\circ} 24^{\prime} 00^{\prime \prime} \mathrm{O}\right)$. The location presents a rainy temperate climate with Mediterranean influence, mountain weather and icy climate by the effect of height due to being Cordillera Pre-Andean zone. The rate of bovine liver seized by $F$. hepatica in slaughtering industries in the region is approximately 30\% (SALAS, 2003). The hare hunters were authorized by the governmental service SAG (Servicio Agrícola y Ganadero), according to the national hunting law (SAG, 2015). Necropsy, liver dissection and histopathological analysis to determine mature and immature forms of $F$. hepatica and lesions compatible were performed at Unidad de Anatomía Patológica Veterinaria, Universidad Austral de Chile. After being fixed in $4 \%$ tamponed formaldehyde, sections of liver were processed according to routine histology techniques and then stained with hematoxylin-eosin (HE). The isolated parasites were dehydrated by a series of alcohol concentrations, $10 \%$ to absolute alcohol, then stained with Semichon's acetocarmine stain, cleared in methyl salicylate and finally mounted on slides with Canada balsam. The parasites were photographed and measured with the software ScopeImage v9.0 associated to a light microscope SudeLab. All measurements were expressed in $\mathrm{mm}$ and then compared with Valero et al. (2001, 2005, 2012), Jones (2005), Periago et al. (2006, 2008), Mezo et al. (2013) and Cuervo et al. (2015). The parameters of prevalence $(\mathrm{P})$ and infection intensity $(\mathrm{I})$ were calculated and interpreted according to Bush et al. (1997). All parasites were deposited in the collection of Unidad de Parasitología Veterinaria, Universidad Austral de Chile (1185-1188Parasitol.UACh).

Only one in 42 hares was infected with helminths and evidenced hepatic lesions compatible with the liver fluke. In the macroscopic inspection of the carcass of the infected hare, peritonitis with a marked hepatomegaly was evident along with notorious dilatation of bile ducts and output of liver flukes. The hepatic flukes were identified as F. hepatica $(\mathrm{P}=2.4 \% ; \mathrm{I}=6)$ (Figure 1a-e). All isolated specimens were gravid flukes with morphological and morphometric characters coincident with previous authors (Table 1). The histopathological findings corresponded to hyperplasia and hypertrophy of bile ducts, portal fibrosis and sections of adult flukes $F$. hepatica-like and trematode-like eggs. In some areas, the wall of biliary ducts was infiltrated with inflammatory cells together with multiple fluke-like eggs, and a fibroblastic response suggesting chronicity of lesions (Figure 1f-h). No migration tracks, granulomatous response nor immature flukes were detected at histopathology.

The present finding suggests European hare as an additional definitive host for $F$. hepatica in Chile, considering previous local reports from European rabbit (COURTIN et al., 1975, 1979; ALCAÍNO et al., 1988; APT et al., 1993; ALCAÍNO \&
GORMAN, 1999). Furthermore, there are only two previous records from South America, both surveys restricted to Argentina (KLEIMAN et al., 2004; CUERVO et al., 2015). Therefore, to our knowledge, the present finding would be the first for Chile and the third in South America.

The lesions reported in the present study are characteristic for the biliary or chronic infection period with inflammation and hyperplasia

Table 1. Comparative measurements of Fasciola hepatica isolated in hares (Lepus europaeus) from Chile (present study) and Argentina (CUERVO et al., 2015).

\begin{tabular}{|c|c|c|}
\hline Country & Chile & Argentina \\
\hline $\mathrm{BL}$ & $12.87-16.56(15.14 \pm 1.52)$ & $7.47-11.35(9.13 \pm 1.54)$ \\
\hline BW & $6.33-8.78(7.46 \pm 1.08)$ & $3.23-4.53(4.01 \pm 0.47)$ \\
\hline $\mathrm{BA}^{\dagger}$ & $91.16-145.43(113.70 \pm 25.14)$ & $22.7-32.4(25.7 \pm 3.9)$ \\
\hline OSDmin & $0.42-0.77(0.56 \pm 0.14)$ & $0.50-0.56(0.52 \pm 0.02)$ \\
\hline OSDmax & $0.68-0.83(0.77 \pm 0.06)$ & $0.61-0.69(0.63 \pm 0.04)$ \\
\hline VSDmin & $0.93-1.09(1.00 \pm 0.07)$ & $0.17-0.24(0.20 \pm 0.03)$ \\
\hline VSDmax & $1.02-1.28(1.11 \pm 0.10)$ & $0.32-0.49(0.41 \pm 0.07)$ \\
\hline $\mathrm{OSA}^{\dagger}$ & $0.33-0.60(0.44 \pm 0.12)$ & $0.27-0.32(0.30 \pm 0.02)$ \\
\hline VSA & $0.96-1.39(1.11 \pm 0.17)$ & $0.6-0.7(0.60 \pm 0.05)$ \\
\hline PL & $0.43-0.62(0.54 \pm 0.08)$ & $0.48-0.68(0.55 \pm 0.12)$ \\
\hline PW & $0.32-0.46(0.40 \pm 0.06)$ & $0.30-0.32(0.31 \pm 0.01)$ \\
\hline $\mathrm{PA}^{\dagger}$ & $0.15-0.26(0.22 \pm 0.04)$ & $0.11-0.16(0.13 \pm 0.03)$ \\
\hline CCL & $1.23-1.81(1.61 \pm 0.22)$ & $0.85-1.49(1.06 \pm 0.26)$ \\
\hline $\mathrm{CCW}$ & $2.35-3.08(2.63 \pm 0.33)$ & $1.23-2.32(1.59 \pm 0.39)$ \\
\hline UL & $1.27-2.95(1.97 \pm 0.64)$ & - \\
\hline UW & $1.23-3.39(2.23 \pm 0.78)$ & - \\
\hline $\mathrm{UA}^{\dagger}$ & $1.57-10.02(4.77 \pm 3.19)$ & - \\
\hline $\mathrm{TL}$ & $5.36-8.79(7.53 \pm 1.53)$ & $2.85-4.08(3.56 \pm 0.57)$ \\
\hline TW & $3.77-5.09(4.55 \pm 0.52)$ & $1.87-2.72(2.09 \pm 0.36)$ \\
\hline $\mathrm{TA}^{\dagger}$ & $25.22-44.71(34.32 \pm 8.65)$ & $5.57-6.78(6.24 \pm 0.49)$ \\
\hline $\mathrm{EL}^{*}$ & $89.92-144.87(118.52 \pm 14.22)$ & $90.5-143.7(120.0 \pm 8.9)$ \\
\hline $\mathrm{EW}^{*}$ & $59.87-81.90(72.45 \pm 5.42)$ & $56.6-86.2(68.9 \pm 4.9)$ \\
\hline $\mathrm{EA}^{* *}$ & $5626.3-11117.1(8631 \pm 1465.1)$ & $6142.4-11408.7(8275.1 \pm 919.3)$ \\
\hline dAE-VS & $1.34-1.73(1.57 \pm 0.15)$ & $0.65-1.23(0.99 \pm 0.24)$ \\
\hline dOS-VS & $0.70-1.28(1.02 \pm 0.25)$ & $0.33-0.80(0.65 \pm 0.24)$ \\
\hline dVS-UVi & $7.26-10.14(8.83 \pm 1.20)$ & $4.22-6.55(5.69 \pm 1.05)$ \\
\hline dVS-PE & $10.61-13.84(12.61 \pm 1.32)$ & $6.73-9.26(7.86 \pm 0.94)$ \\
\hline dUVi-PE & $3.35-4.06(3.78 \pm 0.33)$ & $1.29-2.74(2.17 \pm 0.55)$ \\
\hline BL/BW & $1.75-2.37(2.05 \pm 0.26)$ & $1.68-3.22(2.33 \pm 0.63)$ \\
\hline BL/dVS-PE & $1.19-1.21(1.20 \pm 0.01)$ & $1.07-1.32(1.16 \pm 0.09)$ \\
\hline OSA/VSA & $0.28-0.63(0.41 \pm 0.15)$ & $0.43-0.57(0.50 \pm 0.05)$ \\
\hline EL/EW & $1.36-2.02(1.64 \pm 0.16)$ & $1.3-2.3(1.7 \pm 0.2)$ \\
\hline
\end{tabular}

All values expressed in mm unless otherwise stated; ${ }^{*} \mu \mathrm{m} ;{ }^{* *} \mu \mathrm{m}^{2}$; and $\mathrm{mm}^{2} ; \mathrm{BL}=$ Body length; $\mathrm{BW}=$ Body width; $\mathrm{BA}=$ Body area; $\mathrm{OSDmin}=$ Minimum oral sucker diameter; OSDmax = Maximum oral sucker diameter; VSDmin = Minimum ventral sucker diameter; VSDmax $=$ Maximum ventral sucker diameter; OSA = Oral sucker area; VSA = Ventral sucker area $\mathrm{PL}=$ Pharynx length; $\mathrm{PW}=$ Pharynx width $\mathrm{PA}=$ Pharynx area $\mathrm{CCL}=$ Cephalic cone length; $\mathrm{CCW}=$ Cephalic cone width; $\mathrm{UL}=$ Uterus length; $\mathrm{UW}=$ Uterus width; $\mathrm{UA}=$ Uterus area; $\mathrm{TL}=$ Testicular length; $\mathrm{TW}=$ Testicular width; $\mathrm{TA}=$ Testicular area; $\mathrm{EL}=$ Eggs length; EW = Eggs width; EA = Eggs area; $\mathrm{dAE}-\mathrm{VS}$ = Distance between anterior end of body and ventral sucker; dOS-VS = Distance between oral sucker and ventral sucker; $\mathrm{dVS}-\mathrm{UVi}=$ Distance between ventral sucker and union of vitelline glands; dVS-PE $=$ Distance between ventral sucker and posterior end of body; dUVi-PE = Distance between union of vitelline glands and posterior end of body; $\mathrm{BL} / \mathrm{BW}=$ Body length/body width ratio; $\mathrm{BL} / \mathrm{dVS}-\mathrm{PE}=$ Body length/distance between ventral sucker-posterior end of body; OSA/VSA = Oral sucker area/ventral sucker area ratio; EL/EW = Eggs length/Eggs width ratio. 
of biliary ducts walls. Lesions were mostly around portal spaces with characteristic dilatation of bile ducts which were hyperplastic and filled with cellular debris, eggs and flukes as was reported by
Urquhart (1956), Santarém et al. (2006), Mendes et al. (2012), Ashrafi et al. (2014) and Labruna et al. (2018). Alcaíno et al. (1988) suggested that mild parasitic load, i.e. 4-10 flukes, could be equally

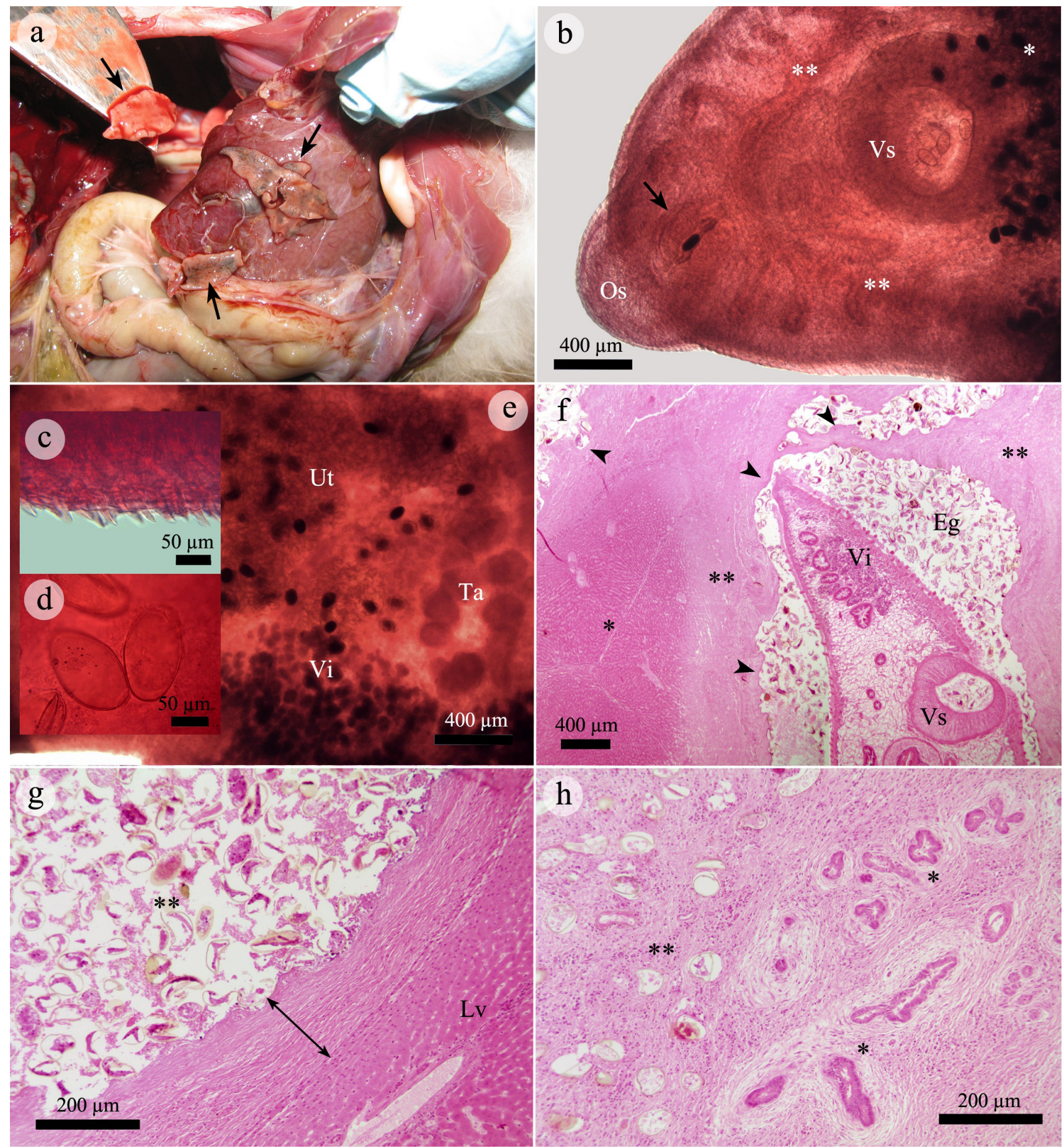

Figure 1. (a) Flukes (arrows) isolated after cutting hepatic parenchyma, note its typical morphology; (b) Cephalic cone of fluke with its oral sucker (Os), kidney-shaped pharynx (arrow), ventral sucker $(\mathrm{Vs})$, intestine $\left(^{* *}\right)$ and uterus $\left({ }^{*}\right)$; (c) Close-up of tegument, note small spines covering its surface; (d) Typical trematode-like eggs with its operculum; (e) Ovigerous uterus (Ut), lateral vitellaria (Vi) and testicular area (Ta); (f) Histopathological section of liver with $F$. hepatica inside a biliary duct filled with trematode-like eggs (Eg), note ventral sucker (Vs), vitellaria (Vi) and small spines over the tegument. The border of biliary epithelium is irregular (arrow heads), being hypertrophied and replaced with fibrosis $\left({ }^{*}\right)$. Normal hepatic parenchyma $\left({ }^{*}\right)$; $(\mathrm{g})$ Close-up of biliary duct, there is evident fibrosis of the duct wall (double arrow) with an irregular epithelial border and lumen filled with eggs $\left({ }^{* *}\right)$. Normal hepatic parenchyma (Lv); (h) Hyperplasia of biliary ducts $\left({ }^{*}\right)$ surrounded by a mild fibrosis and an inflammatory response around trematode-like eggs embedded in the parenchyma $\left(^{* *}\right)$. 
pathogenic to the lagomorph host, agreeing with the parasitic load found in this study. On the other hand, the peritonitis observed in the hare affected could be associated to track-like lesions associated to young flukes or to migration of adult parasites to peritoneal cavity and other organs in pursuit for feeding (MENDES et al., 2012; LABRUNA et al., 2018).

Regarding morphometric data, the values are similar in comparison to those from hares reported by Cuervo et al. (2015). Unfortunately, descriptions of flukes from wild mammals are focused mainly in length and width (COURTIN et al., 1979; MÉNARD et al., 2001; SANTARÉM et al., 2006; GAYO et al., 2011), probably because its typical shape which is used as the most important diagnosis criteria. In spite of the above, there is evidence of environmental and host influence over the morphology of flukes and its eggs (VALERO et al., 2001, 2012; PERIAGO et al., 2006; MAS-COMA et al., 2007), thus is important to record these data to a better understanding of the parasite development. In the present study, it was notorious the small size of flukes in comparison to those from domestic animals, which could be consequence of the microhabitat given by biliary ducts (VALERO et al., 2001, 2012; PERIAGO et al., 2008; CUERVO et al., 2015). Eggs count was not performed in the present study, however, the presence of ovigerous specimens and biliary ducts with eggs at histopathology suggest that hare is a potential definitive host (CUERVO et al., 2015).

Notwithstanding the small sample size, the low prevalence is similar to previous studies attempted in hares from Argentina (0.08 to 3.7\%) (KLEIMAN et al., 2004; CUERVO et al., 2015), Poland and Belarus (2.2\% to 9.1\%) (CZAPLIŃSKA et al., 1965; SHIMALOV \& SHIMALOV, 2000; SHIMALOV, 2001). In spite of above, Cuervo et al. (2015) recorded a highest prevalence of $14.3 \%$ including coprological methods; yet, only 1 hare was positive to liver flukes (3.7\%; see above). The coprological studies of uncontrolled environments, as occur with samples from wild species, can be biased due to a pseudoparasitism caused by accidental ingestion of fasciolid eggs from pastures (PINTO et al., 2014). In comparison to reports from rabbits, there are similar prevalence recorded from Central Chile; 2.9 to 6.8\% (COURTIN et al., 1975, 1979; ALCAÍNO et al., 1988; APT et al., 1993) and North America; 4.2\% (OLSEN, 1948). In spite of the above, there are reports with higher prevalence in hares from France and Netherlands (12.7\% to 39.2\%) (BAILENGER et al., 1965; RONDELAUD et al., 2001; WALKER et al., 2011) and North America (18.1\%) (OLSEN, 1948), and similarly for rabbits from France (25 to 42\%) (MÉNARD et al., 2000; RONDELAUD et al., 2001). The parasitic load recorded in the present study $(n=6)$ was comparable to previous surveys from North America; 1-7 flukes (OLSEN, 1948) and Europe; 1-8 flukes per animal (SHIMALOV \& SHIMALOV, 2000; RONDELAUD et al., 2001; SHIMALOV, 2001; WALKER et al., 2011). Nevertheless, Walker et al. (2011) and Cuervo et al. (2015) recorded highest parasitic loads with 35 and 22 flukes from 1 hare, respectively. In the case of rabbits, a similar situation has been reported from Chile; 1-17 flukes (COURTIN et al., 1975, 1979; ALCAÍNO et al., 1988; APT et al., 1993), North America; 3 flukes (OLSEN, 1948) and Europe; 1-6 flukes per animal (CZAPLIŃSKA et al., 1965; RONDELAUD et al., 2001). There is a clear need of additional research about the prevalence, infection intensity and additional wild hosts for this fluke in South America, considering the few records are mainly from rabbits.

The relevance of this finding lies in the potential of this mammal acting as reservoir of fascioliasis both to human, domestic and wild animals just like has been proposed by other authors (e.g., OLSEN, 1948; BAILENGER et al., 1965; RONDELAUD et al., 2001; KLEIMAN et al., 2004; WALKER et al., 2011; CUERVO et al., 2015). Furthermore, according to Muñoz-Pedreros and Yañez (2009) this lagomorph has a wide distribution in the country, consequently it could favor the spread of this parasite into a wide geographic area considering a daily release between 410 and 1772 eggs of $F$. hepatica per hare (CUERVO et al., 2015). However, it is necessary to evaluate the hatchability of released eggs, capacity of miracidiae to infect local lymnaeid snails and developing of intramolluscan stages to finally form the metacercariae. Then, experimental infections in other mammal hosts different from hares would be necessary to assess its infectivity (MÉNARD et al., 2001; KLEIMAN et al., 2004).

The present survey together with previous reports from European rabbits, highlight the role of both lagomorphs as wild reservoirs for animal and human fascioliasis in the country (COURTIN et al., 1975; ALCAÍNO et al., 1988). On the other hand, there is a need of parasitological surveys from protected native ruminants such as Taruca (Hippocamelus antisensis), Huemul (H. bisulcus) and Pudu (P. puda), and threatened native marsupials and rodents (see JAKSIC et al., 2002; MUÑOZ-PEDREROS \& YAÑEZ, 2009) which could act as definitive hosts as well (MÉNARD et al., 2000, 2001; SANTARÉM et al., 2006; GAYO et al., 2011; MENDES et al., 2012; FUGASSA, 2015; LABRUNA et al., 2018). This information, combined with histopathological analysis when possible, would allow to assess the potential threat of this fluke to the health of these native mammals. Also is important to consider the potential role as reservoirs of feral introduced mammals such boars and deers, which also acts as hosts for this parasite (SHIMALOV \& SHIMALOV, 2000; MEZO et al., 2013). Finally, this finding constitute a precedent for future research concerning the epidemiology and control programs, considering Chile as an endemic country for this important fluke (WHO, 2018) which has implications for human, livestock and wildlife health.

\section{Acknowledgements}

Authors are grateful of Dr. Bruno Menarim for the translation to Portuguese language, also to Jesús Alvelo for the revision of manuscript and to the anonymous reviewers for their important suggestions.

\section{References}

Alcaíno H, Gorman T. Parásitos de los animales domésticos en Chile. Parasitol Día 1999; 23(1-2): 33-41. http://dx.doi.org/10.4067/S071607201999000100006.

Alcaíno H, Vega F, Klein P, Gorman T, Apt W. Fascioliasis en caballos y conejos silvestres (Oryctolagus cuniculus) en la Provincia de Curicó, Chile. Parasitol Día 1988; 12(3): 136-140. 
Apt W, Aguilera X, Vega F, Alcaíno H, Zulantay I, Apt P, et al. Prevalencia de fascioliasis en humanos, caballos, cerdos y conejos silvestres, en tres provincias de Chile. Bol of Sanit Panam 1993; 115(5): 405-414.

Ashrafi K, Bargues MD, O’Neill S, Mas-Coma S. Fascioliasis: a worldwide parasitic disease of importance in travel medicine. Travel Med Infect Dis 2014; 12(6): 636-649. http://dx.doi.org/10.1016/j.tmaid.2014.09.006. PMid:25287722.

Bailenger J, Tribouley J, Amyot B, Duret J. Importance des Léporidés comme réservoirs sauvages dans répidémiologie des distomatoses à Fasciola hepatica et Dicrocoelium dendriticum. Ann Parasitol Hum Comp 1965; 40(1): 51-54. http://dx.doi.org/10.1051/parasite/1965401051. PMid:14330318.

Bush AO, Lafferty KD, Lotz JM, Shostak AW. Parasitology meets ecology on its own terms: Margolis et al. revisited. J Parasitol 1997; 83(4): 575583. http://dx.doi.org/10.2307/3284227. PMid:9267395.

Courtin S, Alcaíno H, Plaza J, Ferriere G. Platelmintos del conejo silvestre (Oryctolagus cuniculus) en la cordillera de Nahuelbuta, Chile. Arch Med Vet 1979; 11(1): 23-26.

Courtin S, Ferriere G, Cerda J. Primer estudio de Fasciola hepatica en el conejo silvestre (Oryctolagus cuniculus) de la precordillera de Nahuelbuta. Bol Chil Parasitol 1975; 30(3-4): 65-68. PMid:1212282.

Cuervo PF, Cataldo SD, Fantozzi MC, Deis E, Isenrath GD, Viberti $\mathrm{G}$, et al. Liver fluke (Fasciola hepatica) naturally infecting introduced European brown hare (Lepus europaeus) in northern Patagonia: Phenotype, prevalence and potential risk. Acta Parasitol 2015; 60(3): 536-543. http:// dx.doi.org/10.1515/ap-2015-0076. PMid:26204194.

Czaplińska D, Czapliński B, Rutkowska M, Zebrowska D. Studies on the European hare. IX. Helminth fauna in the annual cycle. Acta Theriol 1965; 10(4): 55-78. http://dx.doi.org/10.4098/AT.arch.65-4.

Fugassa MH. Checklist of helminths found in Patagonian wild mammals. Zootaxa 2015; 4012(2): 271-328. http://dx.doi.org/10.11646/ zootaxa.4012.2.3. PMid:26623857.

Gayo V, Cuervo P, Rosadilla D, Birriel S, Dell'Oca L, Trelles A, et al. Natural Fasciola hepatica Infection in Nutria (Myocastor coypus) in Uruguay. JZoo Wildl Med 2011; 42(2): 354-356. http://dx.doi.org/10.1638/20100226.1. PMid:22946422.

González-Acuña D, Rebolledo P, Skewes O, Moreno L, Castro D. Parásitos de la liebre (Lepus europaeus Pallas, 1778): estudio en dos zonas geográficas de Chile. Parasitol Latinoam 2005; 60(3-4): 174-177. http:// dx.doi.org/10.4067/S0717-77122005000200013.

Jaksic FM, Iriarte JA, Jiménez JE, Martínez DR. Invaders without frontiers: cross-border invasions of exotic mammals. Biol Invasions 2002; 4(1-2): 157-173. http://dx.doi.org/10.1023/A:1020576709964.

Jones A. Family Fasciolidae Railliet, 1895. In: Jones A, Bray RA, Gibson DI, editors. Keys to the Trematoda. London: CABI Publishing and The Natural History Musem; 2005. p. 79-85. (vol. 2). http://dx.doi.org/10 $.1079 / 9780851995878.0079$.

Kleiman F, González N, Rubel D, Wisniveksy C. Fasciola hepatica (Linnaeus, 1758) (Trematoda, Digenea) in the hare Lepus europaeus, Pallas 1778 (Lagomorpha, Leporidae) from the Andean Patagonian region, Chubut Province, Argentina. Parasitol Latinoam 2004; 59(1-2): 68-71.

Labruna MB, Costa F, Port-Carvalho M, Oliveira A, Souza S, Castro M. Lethal Fascioliasis in Capybaras (Hydrochoerus hydrochaeris) in Brazil. J Parasitol 2018; 104(2): 173-176. http://dx.doi.org/10.1645/17-114. PMid:29185852.
Mas-Coma S, Bargues MD, Valero MA. Plant-borne trematode zoonoses: Fascioliasis and Fasciolopsiasis. In: Murrell KD, Fried B, editors. World class parasites: food-borne parasitic zoonoses. New York: Springer Science+Business Media; 2007. p. 293-334. http://dx.doi. org/10.1007/978-0-387-71358-8_9.

Mas-Coma S, Valero MA, Bargues MD. Fasciola, lymnaeids and human fascioliasis, with a global overview on disease transmission, epidemiology, evolutionary genetics, molecular epidemiology and control. Adv Parasitol 2009; 69(9): 41-146. http://dx.doi.org/10.1016/S0065-308X(09)69002-3. PMid:19622408.

Ménard A, Agoulon A, L'Hostis M, Rondelaud D, Collard S, Chauvin A. Myocastor coypus as a reservoir host of Fasciola hepatica in France. Vet Res 2001; 32(5): 499-508. http://dx.doi.org/10.1051/vetres:2001141. PMid:11592619.

Ménard A, L'Hostis M, Leray G, Marchandeau S, Pascal M, Roudot $\mathrm{N}$, et al. Inventory of wild rodents and lagomorphs as natural hosts of Fasciola hepatica on a farm located in a humid area in Loire Atlantique (France). Parasite 2000; 7(2): 77-82. http://dx.doi.org/10.1051/ parasite/2000072077. PMid:10887652.

Mendes EA, Vasconcelos AC, Lima WDS. Histopathology of Fasciola hepatica infection in Meriones unguiculatus. Rev Patol Trop 2012; 41(1): 55-62. http://dx.doi.org/10.5216/rpt.v41i1.17747.

Mezo M, González-Warleta M, Castro-Hermida JA, Manga-González MY, Peixoto R, Mas-Coma S, et al. The wild boar (Sus scrofa Linnaeus, 1758) as secondary reservoir of Fasciola hepatica in Galicia (NW Spain). Vet Parasitol 2013; 198(3-4): 274-283. http://dx.doi.org/10.1016/j. vetpar.2013.09.009. PMid:24103736.

Muñoz-Pedreros A, Yañez J. Mamíferos de Chile. 2nd ed. Valdivia: CEA Ediciones; 2009.

Olsen OW. Wild Rabbits as Reservoir Hosts of the Common Liver Fluke, Fasciola hepatica, in Southern Texas. J Parasitol 1948; 34(2): 119-123. http://dx.doi.org/10.2307/3273405. PMid:18856293.

Periago MV, Valero MA, El Sayed M, Ashrafi K, El Wakeel A, Mohamed MY, et al. First phenotypic description of Fasciola hepatical Fasciola gigantica intermediate forms from the human endemic area of the Nile Delta, Egypt. Infect Genet Evol 2008; 8(1): 51-58. http://dx.doi.org/10.1016/j. meegid.2007.10.001. PMid:18006385.

Periago MV, Valero MA, Panova M, Mas-Coma S. Phenotypic comparison of allopatric populations of Fasciola hepatica and Fasciola gigantica from European and African bovines using a computer image analysis system (CIAS). Parasitol Res 2006; 99(4): 368-378. http://dx.doi.org/10.1007/ s00436-006-0174-3. PMid:16568331.

Pinto HA, Mati VLT, Melo AL. Toxocara cati (Nematoda: Ascarididae) in Didelphis albiventris (Marsupialia: Didelphidae) from Brazil: a case of pseudoparasitism. Rev Bras Parasitol Vet 2014; 23(4): 522-525. http:// dx.doi.org/10.1590/S1984-29612014074. PMid:25517533.

Povilitis A. Characteristics and conservation of a fragmented population of huemul Hippocamelus bisulcus in central Chile. Biol Conserv 1998; 86(1): 97-104. http://dx.doi.org/10.1016/S0006-3207(97)00161-4.

Rondelaud D, Vignoles P, Abrous M, Dreyfuss G. The definitive and intermediate hosts of Fasciola hepatica in the natural watercress beds in central France. Parasitol Res 2001; 87(6): 475-478. http://dx.doi. org/10.1007/s004360100385. PMid:11411948.

Salas C. Estudio comparativo del efecto de la parasitosis por Fasciola hepatica sobre el higado de los bovinos beneficiados en el matadero FRIVAL de la ciudad de Valdivia, Chile [thesis]. Valdivia: Universidad Austral de Chile; 2003. 
Santarém VA, Tostes RA, Alberti H, Sanches OC. Fasciola hepatica in capybara. Acta Trop 2006; 98(3): 311-313. http://dx.doi.org/10.1016/j. actatropica.2006.05.004. PMid:16774732.

Servicio Agrícola y Ganadero - SAG. La ley de caza y su reglamento [online]. Chile; 2015 [cited 2018 July 28]. Available from: http//www.sag.cl/sites/ default/files/ley_de_caza_y_su_reglamento_2015.pdf

Shimalov VV, Shimalov VT. Findings of Fasciola hepatica Linnaeus, 1758 in wild animals in Belorussian Polesie. Parasitol Res 2000; 86(6): 527. http://dx.doi.org/10.1007/s004360050707. PMid:10894484.

Shimalov VV. Helminth fauna of the hare (Lepus europaeus Pallas, 1778) in the southern part of Belarus. Parasitol Res 2001; 87(1): 85. http:// dx.doi.org/10.1007/s004360000259. PMid:11199857.

Urquhart GM. The pathology of experimental fascioliasis in the rabbit. J Pathol Bacteriol 1956; 71(2): 301-310. http://dx.doi.org/10.1002/ path.1700710205. PMid:13398876.

Valero MA, Darce NA, Panova M, Mas-Coma S. Relationships between host species and morphometric patterns in Fasciola hepatica adults and eggs from the northern Bolivian Altiplano hyperendemic region. Vet
Parasitol 2001; 102(1-2): 85-100. http://dx.doi.org/10.1016/S03044017(01)00499-X. PMid:11705655.

Valero MA, Panova M, Mas-Coma S. Phenotypic analysis of adults and eggs of Fasciola hepatica by computer image analysis system. J Helminthol 2005; 79(3): 217-225. http://dx.doi.org/10.1079/JOH2005301. PMid:16153315.

Valero MA, Perez-Crespo I, Khoubbane M, Artigas P, Panova M, Ortiz P, et al. Fasciola hepatica phenotypic characterization in Andean human endemic areas: valley versus altiplanic patterns analysed in liver flukes from sheep from Cajamarca and Mantaro, Peru. Infect Genet Evol 2012; 12(2): 403-410. http://dx.doi.org/10.1016/j.meegid.2012.01.009. PMid:22285769.

Walker SM, Johnston C, Hoey EM, Fairweather I, Borgsteede FHM, Gaasenbeek CPH, et al. Potential role of hares in the spread of liver fluke in the Netherlands. Vet Parasitol 2011; 177(1-2): 179-181. http://dx.doi. org/10.1016/j.vetpar.2010.11.043. PMid:21232871.

World Health Organization - WHO. Foodborne trematode infections: Fascioliasis [online]. Genebra: WHO; 2018 [cited 2018 July 28]. Available from: http://www.who.int/foodborne_trematode_infections/fascioliasis/en/ 